\title{
Accounting and tax accounting for the accrual of depreciation of fixed assets and ways of convergence
}

\author{
Hafis Hajiyev ${ }^{1, *}$ \\ ${ }^{1}$ Azerbaijan State University of Economics (UNEC), Faculty of "Finance and accounting", \\ Department of "Accounting and Audit", Istiqlaliyyat street 6, AZ1001, Baku, Republic of Azerbaijan
}

\begin{abstract}
.
Research background: As you know, one of the main accounting principles that determine the methodology for assessing the facts of economic life is business continuity. Compliance with this principle by commercial organizations is associated with many factors, one of which is their ability to provide funding for the continuation and development of activities. Carrying out activities for the acquisition of new or modernization and technical re-equipment of existing fixed assets implies one-time cash costs. That is why one of the main sources of financing for updating and modernization and technical re-equipment of fixed assets is depreciation deductions. Depreciation deductions for fixed assets in accounting and tax accounting are calculated differently, which determines the relevance and need for a clear study of accounting procedures in the field of their accounting.

Purpose of the article: The purpose of the article is to conduct a comparative analysis of the procedure for calculating and accounting for depreciation deductions for fixed assets in accounting and tax accounting and to study ways to bring them closer together.

Methods: Methods of comparative analysis, induction and deduction were used in the article.

Findings \& Value added: The current rules for calculating depreciation deductions for fixed assets and their reflection in accounting and reporting do not provide a reliable reflection of the facts of economic activity of the enterprise. And this in turn leads to a misunderstanding by the respective users of the contents of the statement of financial position and the statement of profit or loss and other comprehensive income and the essence of depreciation itself.
\end{abstract}

Keywords: accounting, fixed assets, depreciation, depreciation methods.

JEL Classification: M41; M49.

\footnotetext{
* Corresponding author: hafiz hajiyev@unec.edu.az
} 


\section{Introduction}

In modern conditions, the main goal of organizing entrepreneurial activities of commercial organizations is to increase the efficiency of business, which is expressed in strengthening financial stability in the market and a stable increase in their market value. The achievement of this goal is associated with the presence in commercial organizations of a well-organized and effective accounting and analytical system. The organization of fixed assets accounting in commercial organizations is one of the most important areas in the accounting system, which has a significant impact on the formation of financial results of activities. Fixed assets are one of the productive resources of commercial organizations, the use of which is associated with many internal and external factors of production.

Fixed assets are a part of the property of an organization that has a tangible form that meets certain criteria in accordance with International Financial Reporting Standard 16 "Fixed Assets". An object is recognized as a fixed asset if it: 1) is intended for use in the process of production or goods supply and the provision of services, for leasing or for administrative purposes; 2) expected to be used for more than one reporting period.

The Tax Code of the Republic of Azerbaijan (Article 13.2.17) establishes the following definition of fixed assets: fixed assets are tangible assets, the term of use of which exceeds one year, the value of which exceeds 500 manats and which are subject to depreciation in accordance with Article 114 of present Code.

A commercial organization, being interested both in reducing costs and increasing the productivity of its own fixed assets, seeks to write off their greater value in the first years of beneficial use. And this, along with a decrease in taxable profit, contributes to the acceleration of the renewal of fixed assets. Thus, it is the rational organization of accounting for property depreciation that is one of the sources of economic growth of organizations in the context of scientific and technological progress.

At present, there are differences in theoretical data on depreciation of fixed assets and their application in practice, which is the reason for the lack of positive results when using depreciation methods. To the engineer, the practicing accountant, or the entrepreneur, depreciation may mean a variety of things [1]. So, for example, some scientists call depreciation "the decapitalization of fixed assets", while others consider it a kind of reserve fund for the formation of property. Logically conceived for the purposes of theory, it can connote only one thing - reduction in valuation [1]. The traditional view is that depreciation charges allocate the fall in value of the relevant fixed assets to different accounting periods [9].

\section{Methods}

In accordance with International Financial Reporting Standard 16 "Fixed assets" depreciation of fixed assets refers to the systematic allocation of the depreciable amount of an asset over its beneficial life time. That is, depreciation is assumed to be equal to a fixed amount of money per period over the lifetime of any considered asset [3]. Beneficial life time is the period of time over which an asset is expected to be available for use by an entity; or the number of production or similar units expected to be obtained from the asset by an entity. The beneficial lifetime of an asset is determined in terms of the estimated usefulness of the asset to the entity. An entity's asset management policy may be to dispose of assets after a specified time or after consumption of a specified proportion of the future economic benefits embodied in the asset. Thus, the beneficial life time of an asset may be shorter than its economic life time. The estimate of the beneficial life time of an asset is made using professional judgment based on the entity's experience with similar assets. 
Currently, for accounting purposes, depreciation on fixed assets is calculated using one of the following methods: the straight-line method, the diminishing balance method and the production unit method. Depreciation methods are used for allocating acquisition costs of long-lived assets to individual years that benefit from those assets, eg, in connection with product pricing and regulation of public utilities [7]. The most common depreciation method is the straight-line depreciation method, which consists of calculating a constant amount of depreciation over the beneficial lifetime of the asset, if this does not change the residual value of the asset. The straight-line method has the advantage of causing the least fluctuations in reported earnings [2]. Therefore, the linear depreciation method is simple and accurate, does not require large recalculations of amounts, it is usually used for large objects such as buildings, structures, livestock, etc. Accounting depreciation measured by the straight-line method is set equal to replacement, possibly with a correction for changes in prices [8]. Along with the advantages, this method also has a disadvantage. Thus, it does not provide for the dependence of obtaining economic benefits from the use of the assets of the enterprise. Therefore, it is advisable to use the straight-line depreciation method only if economic benefits are received on a straight-line basis over the entire beneficial life time.

As a result of applying the diminishing balance method, the amount of charged depreciation is calculated from the residual value of the asset and decreases over the beneficial life time. The diminishing balance method has the advantage of changing the value of objects, increasing their wear, but it should not be applied to property with a beneficial life time of less than three years, as well as to cars and office furniture, since these objects have a stable structure and are less subject to physical wear and tear.

The diminishing balance method is the most common accelerated depreciation method. When using the accelerated depreciation method, relatively large amounts of depreciation are in the early years of the asset's beneficial life time and less in later years. This time-flow approach assumes that many types of fixed actives are more efficient when new and therefore provide better service at the beginning of their beneficial lives. The allocation of larger depreciation amounts to early years than subsequent years is consistent with the matching rule if the benefits or services received in the early years are also greater.

Accelerated depreciation also recognizes that advances in technology are causing the service value of some equipment to rapidly decline. If the service of the asset is expected to deteriorate over its life, accelerated depreciation methods are used which allocate larger expenses to earlier years of the asset's life [6]. So it is practical to charge more depreciation in the early years than in subsequent years. New inventions and products lead to obsolescence of previously acquired equipment and necessitate equipment replacement more quickly than if technologies changed more slowly.

Another argument in favor of the accelerated depreciation method is the argument that repair costs are likely to be higher in later periods than in earlier periods. Thus, the total amount of depreciation and repair costs remains fairly constant over time. Such a result naturally assumes that the services received from the asset remain approximately the same from year to year.

The diminishing balance method in international practice is the annual accrual of a depreciation reserve to the balance of value not yet expensed at the end of the previous reporting period. To do this, a fixed percentage is calculated depending on the value of the asset, the applied percentage of depreciation, useful life and net residual value. The annual depreciation amount is calculated by multiplying this fixed percentage by the residual value of the fixed asset. The most commonly used rate is a percentage equal to twice the rate of straight-line depreciation. When double straight-line depreciation rate is used, the method is called the double diminishing balance method. The depreciation rates are double the reciprocal of the service lives in the double-declining balance method [14]. 
The unit-of-production method is to calculate the depreciation amount based on expected use or expected performance. The write-off of value in proportion to the volume of work is used in practice for objects that have a limit on their productivity, that is, the manufacturer indicates the expected output of products for the period of its beneficial life time.

The method of accruing depreciation proportional to the volume of production, also called the production method, has a significant difference from other methods of depreciation. It consists in the fact that the useful life of an asset is not presented in years, but in the form of the expected volume of products that can be produced as a result of its operation. The application of this method allows you to most accurately reflect the actual intensity of the asset use. For example, in the reporting period when the asset will not be used, the accrued depreciation will be 0 . In the periods of more intensive use, when more products are produced, the amount of the accrued depreciation will be higher, and vice versa.

The production-proportional depreciation method has particular practical applicability in the mining sector. According to IFRS 16, when the organization uses the method of writing off the cost in proportion to the volume of production, the annual depreciation rate, as before, is determined based on the natural indicator of the volume of production (work) in the reporting period and the ratio of the difference between the book and liquidation value of the fixed asset item to the expected volume of production (work) for the entire beneficial lifetime of this object.

With regard to the mining sector, when calculated by the unit of production, the annual depreciation is determined as follows: $\mathrm{A}=(\mathrm{V} 1 / \mathrm{V} 2) * \mathrm{NBV}$ FA, where V1 is the volume of resources extracted during the period, $\mathrm{V} 2$ is the reserves of natural resources at the beginning of the reporting period, NBV FA is the residual (book) value of fixed assets depreciated by the per-ton method.

Thus, the annual amount of depreciation deductions is determined: in the linear method based on the initial cost or current (replacement) value (in case of revaluation) of the fixed asset and the depreciation rate calculated based on the beneficial lifetime of this object; in the case of the diminishing balance method - based on the residual value of the fixed assets item at the beginning of the reporting year and the depreciation rate calculated based on the useful life of this item and the acceleration factor; with the depreciation method in proportion to the volume of production - based on the initial cost or the current (replacement) value (in case of revaluation) of the fixed asset and the ratio, in the numerator of which is the actual volume of products produced in the reporting period, and in the denominator - the expected volume of production products over the beneficial lifetime of the asset.

An entity chooses from the above the method that most closely reflects the expected pattern of consumption of the future economic benefits embodied in the asset. The chosen method is applied consistently from one reporting period to the next, unless there is a change in the consumption structure of these future economic benefits. The depreciation method based on the revenue generated from the activities in which the asset is involved is not permitted. The revenue generated from the activities in which the asset is involved generally reflects factors other than the consumption of the economic benefits embodied in the asset. For instance, revenue is affected by other resources and processes used, sales activities, and changes in sales volumes and prices. The price component of revenue can be influenced by inflation, which is not related to the way the asset is consumed.

Depreciation of an asset begins when it becomes available for use, that is, when its location and condition allow it to be operated in accordance with management's intentions. The asset is depreciated on the earlier of the two dates: the date of transfer to assets held for 
sale (or inclusion in a disposal group that is classified as held for sale) or the date the asset is derecognised. So depreciation does not stop when the asset is idle or when the asset is no longer in active use, unless the asset is fully depreciated. However, when using asset-based depreciation methods, the depreciation charge may be zero if the asset is not involved in production.

\section{Results}

For tax purposes, the depreciation charge has significant features. The first feature is the depreciation method used. Article 114 of the Tax Code of the Republic of Azerbaijan prescribes for organizations to use the diminishing balance method. Depreciation deductions for categories of fixed assets are calculated by applying the depreciation rate established for fixed assets belonging to each category to the residual value of fixed assets belonging to this category at the end of the tax year. The annual depreciation rates for depreciated assets are determined in the following order: for capitalized expenses for improving land, buildings, structures and constructions - up to 7\%; for machines and equipment - up to $20 \%$; for computer technology, which is a product of high technologies up to $25 \%$; for vehicles - up to $25 \%$; for working animals - up to $20 \%$; on expenses for exploration and preparatory work for the extraction of natural resources - up to $25 \%$; for intangible assets - for those whose term of use is unknown - up to $10 \%$, and for those whose term of use is known - by years in amounts proportional to the term of use; for other fixed assets - up to $20 \%$. If depreciation rates are lower than those established for the tax year for fixed assets belonging to a category, the difference resulting from this can be added to the depreciation amounts deducted from income in subsequent tax years.

For the purposes of depreciation, the residual value of fixed assets (fixed assets) at the end of the tax year is the amount established in the following order (but not less than zero): to the residual value of fixed assets (fixed assets) at the end of the previous year (the value remaining after deducting depreciation amount accrued for this year), the value of fixed assets (fixed assets) received in the current year in accordance with Article 143 of this Code is added, as well as the over-limit part of repair costs for the current year, established on the basis of Article 115 of this Code, and the residual value of fixed assets provided, liquidated in a tax year or having a residual value of less than 500 manats or 5 percent of the initial cost is deducted. The gain arising from the revaluation of fixed assets (positive difference arising from the revaluation) for the purposes of calculating depreciation is not included in the residual value of fixed assets at the end of the tax year.

When calculating depreciation in tax accounting, it is necessary to exclude land, works of art, buildings, structures (constructions), which are rare historical and architectural monuments, and other wear-resistant assets noted below: 1) equipment, exhibits, samples, operating and non-operating models, models and other visual aids used in classrooms and laboratories for research, educational and practical purposes; 2) productive livestock; 3) exhibits of the animal world, which are in zoos and other similar institutions; 4) perennial plantations with a non-operating life time; 5) library funds, film funds (video, audio, photo), stage props, museum values (exhibits); 6) fully depreciated fixed assets, if they are serviceable; 7) fixed assets that have undergone conservation; 8) public highways; 9) park equipment in common use; 10) fixed assets in warehouses not issued for operation.

The second feature of depreciation in tax accounting is the possibility of using increasing factors. Accelerated depreciation of fixed assets for income tax purposes can be and has been devised in a variety of ways [5]. Thus, micro-entrepreneurship entities in relation to fixed assets used in entrepreneurial activity have the right to deduct depreciation deductions from income using coefficient 2 to the depreciation rates established by Article 
114 of the Tax Code of the Republic of Azerbaijan, and small entrepreneurship entities in relation to fixed assets used in entrepreneurial activity - using a coefficient of 1.5.

\section{Discussion}

Therefore, the depreciation used in determining taxable profit (tax loss) may differ from that used in determining accounting profit. The temporary difference is the difference between the carrying amount of an asset and its tax base, which is equal to the original cost of the asset after taking into account any deductions, related to the asset that the tax authorities allow for determining taxable profit for the current and prior periods.

A taxable temporary difference arises and also results in a deferred tax liability on accelerated tax depreciation (if tax depreciation is slower than accounting depreciation, then a deductible temporary difference and a corresponding deferred tax asset arise).

It should be noted that for the convergence of accounting and tax records for depreciation, economists propose: 1) convergence of concepts such as the initial cost of fixed assets, beneficial life time and replacement cost; 2) convergence of methods for calculating depreciation; 3) convergence of the procedure for applying multiplying coefficients; 4) unification of the beginning and termination of accrual in accounting and tax accounting.

\section{References}

1. Bain, J.S. (1937). Depression Pricing and the Depreciation Function. The Quarterly Journal of Economics, 51(4), 705-715.

2. Barefield, R.M., Comiskey, E.E. (1971). Depreciation Policy and the Behavior of Corporate Profits. Journal of Accounting Research, 9(2), 351-358.

3. Boucekkine, R., Río, F., Martínez, B. (2009). Technological progress, obsolescence, and depreciation. Oxford Economic Papers, 61(3), 440-466.

4. Dietrich, J.R., Harris, M.S., Muller, K.A. (2001). The reliability of investment property fair value estimates. Journal of Accounting and Economics, 30(2), 125-158.

5. Domar, E.D. (1953). The Case for Accelerated Depreciation. The Quarterly Journal of Economics, 67(4), 493-519.

6. Ijiri, Y., Kaplan, R.S. (1969). Probabilistic Depreciation and Its Implications for Group Depreciation. The Accounting Review, 44(4), 743-756.

7. Jennergren, L.P. (2018). A note on the linear and annuity class of depreciation methods. International Journal of Production Economics, 204, 123-134.

8. Jorgenson, D.W., Griliches, Z. (1967). The Explanation of Productivity Change. The Review of Economic Studies, 34(3), 249-283.

9. Lane, J.A., Willett, R.J. (1999). Optimal smoothing of accounting earnings. IMA Journal of Management Mathematics, 10(1), 1-14.

10. Liapis, K.J., Kantianis, D.D., Galanos, C.L. (2014). Commercial property whole-life costing and the taxation environment. Journal of Property Investment \& Finance, 32(1), 56-77.

11. Lin, Y.C., Peasnell, K.V. (2000). Fixed asset revaluation and equity depletion in the UK. Journal of Business Finance and Accounting, 27(2/3), 161-182. 
12. Missonier-Piera, F. (2007). Motives for fixed-asset revaluation: An empirical analysis with Swiss data. The International Journal of Accounting, 42, 186-205.

13. Pakes, A., Griliches, Z. (1984). Estimating Distributed Lags in Short Panels with an Application to the Specification of Depreciation Patterns and Capital Stock Constructs. The Review of Economic Studies, 51(2), 243-262.

14. Sato, K. (1966). On the Adjustment Time in Neo-classical Growth Models. The Review of Economic Studies, 33(3), 263-268.

15. Thalassinos, E., Liapis, K. (2013). A Comparative Analysis for the Accounting Reporting of "Employee benefits" between IFRS and other Accounting Standards: A Case Study for the Biggest Listed Entities in Greece. International Journal of Economics and Business Administration, 1(1), 99-126. 